IZA DP No. 6134

Education, Job Search and Re-employment Outcomes among the Unemployed

W. Craig Riddell

Xueda Song

November 2011

Forschungsinstitut

zur Zukunft der Arbeit

Institute for the Study

of Labor 


\title{
Education, Job Search and Re-employment Outcomes among the Unemployed
}

\author{
W. Craig Riddell \\ University of British Columbia \\ and IZA \\ Xueda Song \\ York University
}

\section{Discussion Paper No. 6134 \\ November 2011}

\author{
IZA \\ P.O. Box 7240 \\ 53072 Bonn \\ Germany \\ Phone: +49-228-3894-0 \\ Fax: +49-228-3894-180 \\ E-mail: iza@iza.org
}

\begin{abstract}
Any opinions expressed here are those of the author(s) and not those of IZA. Research published in this series may include views on policy, but the institute itself takes no institutional policy positions.

The Institute for the Study of Labor (IZA) in Bonn is a local and virtual international research center and a place of communication between science, politics and business. IZA is an independent nonprofit organization supported by Deutsche Post Foundation. The center is associated with the University of Bonn and offers a stimulating research environment through its international network, workshops and conferences, data service, project support, research visits and doctoral program. IZA engages in (i) original and internationally competitive research in all fields of labor economics, (ii) development of policy concepts, and (iii) dissemination of research results and concepts to the interested public.
\end{abstract}

IZA Discussion Papers often represent preliminary work and are circulated to encourage discussion. Citation of such a paper should account for its provisional character. A revised version may be available directly from the author. 
IZA Discussion Paper No. 6134

November 2011

\section{ABSTRACT \\ Education, Job Search and Re-employment Outcomes among the Unemployed ${ }^{*}$}

This study assesses the effects of education on both job search intensity and re-employment success for unemployed workers. Given that the positive correlation between education and job search intensity or re-employment success is likely to be confounded by the endogeneity of education, we make use of data on compulsory schooling laws to create instrumental variables to assess the causal effects of education. Based on data from the Labour Force Survey and the Canadian Census, we find that education both significantly increases job search intensity and significantly improves re-employment success for the unemployed. The evidence on job search intensity provides insights into one potential mechanism through which education may increase the probability of re-employment following unemployment.

JEL Classification: 121, J64

Keywords: education, adaptability, unemployment, job search, causal effects, compulsory schooling laws

Corresponding author:

W. Craig Riddell

Department of Economics

University of British Columbia

\#997 - 1873 East Mall

Vancouver, B.C.

Canada V6T 1 Z1

E-mail: craig.riddell@ubc.ca

\footnotetext{
*Earlier versions were presented at the UBC TARGET Workshop, Economics Research Workshop at York University, the CLSRN Inaugural Conference, and the CLSRN Workshop on Education. We thank Ben Sand, Arthur Sweetman and Daniel Parent for helpful comments and the Canadian Labour Market and Skills Researcher Network and the SSHRC for research support. We also thank Philip Oreopoulos for providing data on compulsory schooling laws in Canada.
} 


\section{Introduction}

The labour market in Canada has been characterized by dramatic structural changes in

recent decades, partly due to technological change, globalization, and the increasingly competitive world economic environment. Workers' adaptability to the changing environment has become increasingly important for both individuals' labour market success and the efficiency of the overall labour market. Whether displaced or unemployed workers are able to adjust efficiently to adverse employment shocks is critical to not only their own welfare, but also the maintenance of healthy communities and efficient allocation of labour resources. As a consequence, building a workforce that can effectively adjust to changing circumstances has acquired heightened status on the policy agenda of the Canadian government. A recent federal government report, for instance, states that "Countries that succeed in the $21^{\text {st }}$ century will be those with citizens who are creative, adaptable and skilled” (Human Resources Development Canada, 2002, p.5). Individuals' adjustment to employment shocks was thus chosen as the target of investigation for this study. Given that the construct of adaptability is multi-dimensional, this study focuses on two key dimensions of the process of adjustment to unemployment and examines the extent to which education influences job search intensity and reemployment success for unemployed workers.

Job search intensity is not only a good indicator of individuals' adaptability to employment shocks, but also a potential mechanism through which education may increase the probability of re-employment following unemployment. An individual's job search intensity during unemployment, such as the number of job search strategies used, reflects the individual's capacity for variation, i.e., the ability to generate new ideas and 
alternative solutions to problems, which is conceptualized as one of the two major dimensions of adaptive capacity (Fullan and Loubser, 1972). A number of studies on reemployment have demonstrated the crucial role of job search behaviour for reemployment (Claussen, 1994; Eden and Aviram, 1993; Holzer, 1988; Schaufeli and Van Yperen, 1993). Holzer, for example, finds that the diversity of job search methods is negatively related to the duration of unemployment. Our investigation of the effects of education on job search intensity thus may help illuminate a mechanism through which education influences the probability of re-employment.

According to job search theory, more educated workers have an incentive to spend more resources in order to shorten the period of unemployment, which is more costly in terms of foregone earnings to them than to less educated workers. Holzer (1988) finds that more educated young unemployed workers use a greater variety of job search methods than their less educated counterparts. Mincer (1991) provides evidence that more educated workers are more efficient in acquiring and processing job search information, and that firms and workers search more intensively to fill vacancies for more skilled workers. Further evidence on greater job search intensity of more educated workers is provided by Barron and Mellow (1979) and Yoon (1981).

As a major adverse employment shock, unemployment is a costly and damaging event for many people (Farber, 2005). How efficiently unemployed workers adapt to the changing environment directly determines re-employment success. Therefore, obtaining re-employment conditional on previously being unemployed is another suitable measure of an individual's adaptability. ${ }^{1}$ Focusing on the post-displacement adjustment process,

\footnotetext{
${ }^{1}$ The relationship between education and the probability of re-employment or leaving unemployment can be readily analyzed using a job search model. According to the theory of unemployment duration, the
} 
Farber (2005) finds that job losers with higher levels of education have higher postdisplacement employment rates and are more likely to be re-employed full-time. Using UK data, Nickell (1979) analyzes the relationship between education and unemployment incidence and the relationship between education and unemployment duration. He finds that each year of schooling up to 12 years reduces the expected duration of unemployment by over $4 \%$. The acquisition of some qualifications at ordinary levels or above reduces the expected unemployment duration by $12 \%$. Mincer (1991) similarly demonstrates shorter duration of unemployment for more educated workers.

The positive correlations between education and efficient post-unemployment adjustment found in most previous studies, however, are likely to be confounded by the endogeneity of education, and thus do not necessarily represent true causal effects of education. In particular, the positive associations between education and job search intensity or re-employment success could arise because of unobserved factors that are correlated with both variables. For example, those with more innate ability may acquire more education and more readily adapt to changing circumstances. Similarly, individuals from advantaged backgrounds are likely to acquire more schooling and also likely to enjoy better and more employment opportunities from well-connected social networks. Therefore, positive (partial) correlations between education and job search intensity or the probability of re-employment based on ordinary least squares (OLS) estimates may

probability of leaving unemployment in any period equals the product of the probability of receiving an offer and the probability of this offer exceeding the reservation wage. Lancaster and Nickell (1980) classify the variables affecting the probability of an individual leaving unemployment into four main categories, i.e., personal characteristics, local labour demand, family composition, and income variables. 
overestimate the effects of education and fail to reveal the true causal link between education and these two dimensions of adaptability. ${ }^{2}$

To overcome the endogeneity of education problem, we make use of historical changes in compulsory schooling laws as instrumental variables for education. Based on data from the Labour Force Survey (LFS) and the Canadian Census, we find that education both significantly increases job search intensity and significantly improves reemployment success for the unemployed. Based on LFS data, for example, our instrumental variable (IV) estimates imply that graduating from high school increases the number of job search methods used in a month conditional on being unemployed in that month by 0.2. An additional year of schooling increases that by 0.02 . Based on LFS and Census data, the probability of re-employment among the unemployed is 16 to 20 percentage points higher for high-school graduates than for those who did not complete high school, with each additional year of schooling leading to a 1.3 to 1.5 percentagepoint increase in the probability of re-employment.

A potentially important issue in analyzing factors that influence search intensity and re-employment outcomes is that the sample consists only of the unemployed, which may result in sample selection bias. ${ }^{3}$ Education may affect the chances of becoming unemployed and hence the characteristics of individuals in the sample. For example, more educated workers may be more likely to voluntarily leave their jobs, and may also transition more quickly to a new job. We address the sample selection issue in various

\footnotetext{
${ }^{2}$ Card (2001) and Griliches (1977) discuss the endogeneity of education and the potential biases of OLS estimates of return to schooling.

${ }^{3}$ It is worth noting that the vast literature on the impacts of education on earnings faces a similar problem of potential selection bias -- the sample consists only of those employed. If schooling influences labour force participation or the probability of being employed conditional on participation, estimated returns to education are potentially subject to selection bias.
} 
ways (discussed subsequently). Our conclusion is that there is little evidence of bias in our estimates of the impact of schooling on search intensity and re-employment success.

Findings from this study not only shed light on the causal relationships between education and individuals' adaptability, but also contribute to the growing literature on the private and social benefits of education. Further, this study bears several implications for public policy. First, it provides empirical evidence that supports education as an effective means to enhance adaptability, a valuable characteristic in a changing labour market. Second, to the extent that education improves adaptability, the private and social benefits of education may be understated by standard outcome measures (e.g., earnings). Third, it lends support to the case for education as a "preventative" alternative to government-sponsored adjustment assistance policies, which are often based on a "repair shop” model that deals with problems ex post. As is believed to be the case with health care, preventative strategies may be more efficient than "repair shop" strategies in addressing labour market challenges.

In a related study using U.S. data we identify a causal link between schooling and re-employment outcomes among the unemployed (Riddell and Song, 2011). The additional contribution of this paper is twofold. First, we provide rather strong evidence that in Canada's labour market education enhances the ability of unemployed workers to obtain re-employment, strengthening the view that this is a consequence of schooling that applies in many settings. Second, we provide new evidence (to our knowledge, the first such evidence) that formal education exerts a causal impact on job search intensity, thus providing insights into one mechanism that links education and re-employment success. 
The remainder of the paper is organized as follows. In Sections 2 and 3, we report and discuss empirical results on the effects of education on job search intensity and the probability of re-employment following unemployment. We discuss the differences between the OLS and IV estimates in Section 4 and conclude in Section 5.

\section{The Effects of Education on Job Search Intensity}

This section presents empirical evidence on the causal effects of education on job search intensity based on data from the LFS. Given that our aim is to determine whether education has any causal role in the post-unemployment adjustment process rather than to determine the magnitude of its effect relative to the effects of other factors, we restrict our analytic model to a simple, reduced form specification without developing a structural model of the re-employment process.

\section{Data and Measures}

Our analysis of job search intensity relies on LFS data over the period 1976 to 1996 , which provides rich information on labour market activities each month over two decades. In the LFS, each respondent remains in the sample for six consecutive months. Each month, approximately one sixth of the sample exits from the survey and is replaced by an incoming rotation group. The rotation group feature of the LFS makes it possible to link individuals longitudinally across the six months that respondents remain in the survey. For this study, we make use of an augmented LFS data file that contains the public use data on each respondent in each month as well as the respondent's labour force 
status (i.e., employment, unemployment, or out-of-the labour force) and job search activity in all subsequent months that the respondent remains in the survey. ${ }^{4}$

The LFS provides rich information on the methods that the respondents use in job search while unemployed, such as checking with a public employment agency, checking with employers directly, contacting relatives, looking at advertisements, placing or answering advertisements, and other methods. ${ }^{5}$ According to Jones and Riddell (1999), active job search methods are more productive in generating employment than passive search methods (i.e., looking at advertisements). Indeed, countries such as the U.S. do not classify people who use only passive methods as searching for jobs, and thus as unemployed (Riddell, 2005). Thus we measure search intensity by the number of active job search methods used in a month conditional on being unemployed in that month. ${ }^{6}$

In January 1990, the LFS revised the questions used to measure educational attainment. In both the original and the revised questionnaires, the questions about education were asked in two parts: number of years of primary and secondary schooling and number of years of post-secondary education. Starting in January 1990, however, the question on the number of years of primary and secondary schooling completed was replaced by a question on the highest grade completed and the response categories were reduced from six to three. A new question was added on whether or not the respondent graduated from high school. Moreover, the response categories for post-secondary education were increased from three to six.

\footnotetext{
${ }^{4}$ We thank Statistics Canada for providing this augmented data file.

${ }^{5}$ The LFS classifies individuals as unemployed if they did not have work in the reference week, were available for work and searched during the previous four weeks. Exceptions to the job search requirement are those on temporary layoff and those with a job to start within the next four weeks.

${ }^{6}$ Wadsworth (1991) argues that the number of search methods used (extensive search) is a better measure of search intensity than is time spent searching (intensive search). In any event, time spent searching is not available in the LFS.
} 
For this study, we construct three measures of educational attainment: a set of dummy variables for five educational levels according to the LFS coding; high-school graduation; and number of years of schooling. The five education levels represented by the set of dummy variables are as follows: 0 to 8 years; some secondary or high-school graduate; some post-secondary; post-secondary certificate or diploma; and university degree. Because no information is available on whether the respondent had graduated from high school in surveys administered before 1990, we define "high-school graduation” as equivalent to "number of years of schooling equals or exceeds 12."

The LFS reports number of years or highest grade of elementary and secondary school ever completed or attended in three categories for those with 13 years of schooling or less: (1) less than 9 years, (2) 9 to 10 years, and (3) 11 to 13 years. For each category, we take the mid-point (4, 9.5, and 12 years respectively) in our analysis. For individuals who report some post-secondary education, we assign 13 years of schooling. For individuals holding a post-secondary certificate or diploma, we assign 14 years of schooling. For individuals holding a university degree, we assign 16 years of schooling. For individuals with a graduate degree (available in post-1990 data), the years of schooling is set to be 18 .

We restrict the sample to those aged 20-64. Because an individual may be unemployed for several months, there may be up to six observations on the same individual in the unemployed sample. In order to avoid "double counting” we impose the restriction that a specific individual can enter the sample only once. We do so by using the job search information in the first month that the individual is classified as unemployed. We also drop from the sample those on temporary lay-off or waiting for a 
job to start, as these individuals are not required to be searching for work in order to be classified as unemployed. ${ }^{7}$ To restrict our sample to active searchers, we drop unemployed individuals whose number of active job search methods used in a month is zero, which results in a final sample size of 451,120 . The sample descriptive statistics reported in Table 1 show that the average number of active job search methods used in a month conditional on being unemployed in that month is 1.6. The average number of years of completed schooling is 11.4 , and $68 \%$ of our sample has a high-school degree.

\section{OLS Estimates}

We first report OLS estimates of the impact of education on the number of active job search methods used in a month conditional on being unemployed in that month. We use 8 years of schooling or less as the base category and regress job search intensity on the complete set of educational attainment dummies. The regression also controls for survey year, survey month, province of residence, nine age groups (age 20-24, 25-29, and so on), gender, and marital status. As shown in Figure 1, there is a steady increase in job search intensity with an increase in schooling level as represented by the set of educational attainment dummies.

Ideally, we would like to estimate a general model where the effect of education on job search intensity varies across years of schooling or levels of attainment. This is not empirically feasible, however, because the instruments we use are limited in both the range of schooling years affected and the amount of actual variation. Therefore, we use a dummy for high-school graduation or years of schooling as the main independent variables.

\footnotetext{
${ }^{7}$ These two groups also have much higher transition rates into employment than unemployed job searchers (Jones and Riddell, 1999, 2006).
} 
The OLS estimates of the effects of high-school graduation and years of schooling on job search intensity, presented in Columns (1) and (4) in Table 2 respectively, also indicate that there is a statistically significant partial correlation between education and search intensity. Graduating from high-school is associated with an increase in the number of active job search methods used in a month by 0.12 . An additional year of schooling is associated with an increase in the number of search methods used by 0.02 . OLS results not reported here also indicate that people younger than 45 , males and unmarried people tend to search more intensively than do other unemployed searchers.

\section{Estimates}

The OLS estimates presented above are consistent with the hypothesis that education increases job search intensity. These estimates, however, may reflect the effects of unobserved individual characteristics that influence both job search intensity and schooling choices. To address the endogeneity of education, we use changes in compulsory schooling laws over time and across jurisdictions to instrument for schooling.

Changes in these laws have been shown to have significant effects on educational attainment, and have been a commonly used instrument for education (see, for example, Acemoglu and Angrist, 2000; Lochner and Moretti, 2004; Milligan, Moretti and Oreopoulos, 2004; and Oreopoulos, 2006a).

Using the compulsory schooling laws data compiled by Oreopoulos (2006a), we first create five indicator variables to indicate whether the youngest school leaving age is $12,13,14,15$, or 16 , and another three indicator variables to indicate whether the oldest school entry age is 6,7 , or 8 . Because the LFS does not report the birthplace of the respondents or the province of residence when the respondents turned 6 or 14, we rely on 
the respondents' current province of residence at the time of the survey in linking LFS data with data on compulsory schooling laws. Although this might introduce some measurement error into our instrumental variables, previous studies suggest that such measurement error is not likely to seriously affect the IV estimates (Milligan, Moretti and Oreopoulos, 2004).

Another difficulty in linking LFS data with data on compulsory schooling laws is that LFS public use data only report five-year age groups instead of the exact age of each respondent. We therefore use the mid-point of the age group that a respondent belonged to as the age of the respondent at the time of the survey. We also tried using the lower and upper bounds of the respondent's age group and obtained similar results. ${ }^{8}$

The linkage between the LFS data and data on compulsory schooling laws is therefore established based on each individual's current province of residence at the time of the survey and the year when the individual turned 14 for matching school leaving age or the year the individual turned 6 for matching school entry age. Schmidt (1996) finds that the effects of compulsory schooling laws in the U.S. were largest when matched to individuals at age 14. Acemoglu and Angrist (2000), Lleras-Muney (2002), Schmidt (1996), and Goldin and Katz (2011) adopt the same procedure in their studies based on the U.S. data, while Oreopoulos (2006a) adopts the same procedure when analyzing Canadian data.

Relying on the instrumental variables thus created, we estimate the causal effects of high-school graduation and years of schooling on the total number of active job search methods employed, using specifications identical to those used to obtain the OLS

\footnotetext{
${ }^{8}$ As a robustness check on our LFS results, we also report results based on the Census which provides information on age in years.
} 
estimates. The IV estimation results in Columns (2) and (5) of Table 2 are generated with a model that includes the three indicator variables for school leaving age, and those in Columns (3) and (6) generated with a model that includes the indicator variables for both school leaving age and school entry age as instruments for schooling. Identification of the causal effects of education is based on changes over time in the youngest school leaving age and oldest school entry age in a given province as well as variations in compulsory schooling laws across provinces. The identifying assumption is that conditional on province of residence, cohort of birth, and survey year, the timing of the changes in compulsory schooling laws within each province is orthogonal to unobserved characteristics that affect schooling choices, such as ability and family background.

The first-stage results indicate that, in general, the more stringent the compulsory schooling legislation, the higher the probability of high-school graduation and the more years of schooling completed. Columns (2) and (5) of Table 2 show, for example, that individuals who lived in provinces requiring the youngest school leaving age to be 15 when they were 14 years of age were 17.4 percentage points more likely to have completed high school and acquired 1.8 more years of schooling by the time of the survey compared with individuals living in provinces requiring the youngest school leaving age to be 13 or lower when they were age 14 (the excluded category). ${ }^{9}$ Columns (3) and (6) of Table 2 show, however, that school entry age does not perform well as an instrument for schooling. It has no association with educational attainment. Thus we will place more emphasis on results based on school leaving age alone. ${ }^{10}$

\footnotetext{
${ }^{9}$ Note that the marginal effect of raising the school leaving age from 15 to 16 is negative, a result also obtained by Oreopoulos (2006a), who discusses potential explanations for this apparent anomaly.

${ }^{10}$ One reason may be that school-entry-age laws are often not binding. For example, inspection of NLSCY data indicates that many children enter school at age 6 when school-entry-age laws require entry by at least
} 
To assess the adequacy of the instrumental variables, we perform F-tests for exclusion of instruments in the first-stage regression. As shown in Columns (2) and (5) in the upper panel of Table 2, when the three indicator variables for school leaving age are used as instruments for schooling, the F-statistic is 56 with high-school graduation as the endogenous variable and 79 with years of schooling as the endogenous variable, which suggests strong correlations between the instruments and schooling. Both test statistics are well above the critical values for weak instruments recommended by Stock, Wright and Yogo (2002).

The bottom panel of Table 2 reports IV estimates of the effects of high-school graduation and years of schooling, respectively, on the number of active job search methods used in a month conditional on being unemployed in that month. The IV coefficient for high-school graduation is 0.17 (about $40 \%$ higher than its OLS counterpart) when the three indicator variables for school leaving age are used as the instruments, while the IV coefficient for years of schooling is 0.02 , a bit smaller than its OLS counterpart. All IV estimates are significant at the .10 level or lower, and none are significantly different from the corresponding OLS estimates. We conclude that educational attainment, whether measured by graduating from high school or years of schooling, exerts a causal impact on job search intensity.

\section{The Effects of Education on Re-employment}

We now investigate the impact of schooling on the probability of re-employment. Our primary source of data is, again, the LFS. However, to check the sensitivity of our results

age 7. However, we do find modest effects of school entry laws in some of our subsequent first-stage regressions. For consistency in reporting of results we thus retain the school entry law variables throughout. 
to limitations of the LFS we also utilize the quasi-longitudinal nature of the Canadian Census.

\section{LFS Results}

Our analysis of re-employment relies on the augmented LFS data described previously. A key difference, however, is that we now restrict the sample to those who were unemployed job searchers in their initial month in the LFS, thus ensuring a "level playing field" in terms of the time interval over which re-employment may occur. ${ }^{11}$ For each respondent who was unemployed in the first month of the survey, the outcomes of interest are the probabilities of re-employment in each of the remaining five months before the respondent exits the survey. In addition, we examine the probability of reemployment at any time in the remaining five months in the survey. As before, we restrict the sample to the birth cohorts aged 20-64. The resulting sample size is 249,330, of whom $24 \%$ were employed in the sixth month of their stay in the survey and $40 \%$ became re-employed any time between the second and sixth month of rotation (see Table 3 for sample descriptive statistics). In the first month of rotation, the average duration of unemployment for the full sample is 21.9 weeks, the average number of years of schooling is 11.4 , and $68 \%$ of our sample has a high-school degree.

The measures of educational attainment are identical to those used for analyzing job search intensity. The OLS results using three alternative education measures (i.e., a set of dummy variables for schooling levels, a dummy for high-school graduation, and the number of years of schooling) show consistently positive and significant partial correlations between education and the probability of re-employment, which are similar

\footnotetext{
${ }^{11}$ Of course, many were unemployed prior to entering the LFS. We therefore control for unemployment duration in the empirical analysis.
} 
in size across the second to the sixth month of rotation. Due to space limitations, we only report the results for the effects of education on the probability of re-employment in the sixth month of rotation and at any time between the second and sixth month. ${ }^{12}$

Similar to analyses of job search intensity, we use those with eight years of schooling or less as the base category and regress the probability of re-employment on a set of educational attainment dummies. The regression also controls for survey year, survey month, province of residence, age, gender, marital status, economic family size, and duration of unemployment. As shown in Figure 2, there is a steady increase in the probability of re-employment in the sixth month with higher levels of educational attainment.

Column (1) in Tables 4 and 5 presents the OLS estimates of the effects of highschool graduation and years of schooling respectively on the probability of reemployment based on the full sample, i.e., all those unemployed in the first month of rotation. Table 4, for example, reveals that graduating from high school is associated with a 6.0-percentage-point increase in the probability of re-employment at any time between the second and sixth months of rotation and that an additional year of schooling is associated with a 0.9-percentage-point increase in that probability. Results not reported here also indicate that males, married people, people with a larger family size, and those with a shorter duration of unemployment have a higher probability of obtaining a new job after unemployment.

\footnotetext{
${ }^{12}$ The results on the effects of education on the probability of re-employment in other months are available from the authors. We have also analyzed the relationship between education and full-time re-employment. The estimated effects of education on full-time re-employment are similar to those on re-employment, and are also available by request.
} 
The instrumental variables used for estimating the causal effects of education on re-employment with the LFS data are the same as those used previously for assessing education's effects on job search intensity. The specifications for the IV estimation of education's effects on re-employment are also similar to those used previously.

As shown in Columns (2) and (3) in Tables 4 and 5, the IV estimation results for the full sample are very similar based on the two sets of instruments. Graduating from high school increases the probability of re-employment in the sixth month of rotation by about 16 percentage points, and an additional year of schooling increases such probability by 1.6 percentage points. Regardless of the instruments used, all IV estimates are significant at the .05 level or lower and larger in magnitude than the corresponding OLS estimates, a finding that is discussed later in the paper. The tables also show that all Fstatistics for exclusion of instruments in the first-stage regressions are well above critical values for weak instruments, suggesting strong correlations between our instruments and schooling. One difference from our previous results is that in this sample school entry laws appear to exert an influence, albeit a weak one, on educational attainment.

As discussed in the introduction, a potential concern with our analysis is that the sample consists only of the unemployed, a select subset of the labour force. Education may affect the likelihood of becoming unemployed, leading to potential selection bias. For example, better-educated workers may be over-represented in sectors with high job mobility, or be more likely to quit their jobs and transit quickly to a new opportunity. We address the sample selection issue in several ways. First, to deal with the possibility that more educated workers may be more likely to voluntarily leave their jobs, we exclude from the sample those who entered unemployment by quitting their previous job. 
Excluding "job leavers" results in a sample of 212,218 with a slightly lower level of educational attainment (See Table 3 for summary statistics). According to both the OLS and the IV estimates reported in Columns (4) - (6) in Tables 4 and 5, the estimated impacts of education on re-employment based on this restricted sample are very similar to those based on the full sample.

We further apply our IV strategy to estimating the effect of schooling on transitions into unemployment from either employment or out-of-the-labour force. The impact of education on these transitions provides information on the potential importance of selection bias into our sample of unemployed workers.

Table 6 reports results on the effects of high-school graduation and years of schooling on the probability of being unemployed in the second month of rotation conditional on being employed in the first month. ${ }^{13}$ The OLS estimates suggest a weak negative relationship between education and the likelihood of job loss. However, the IV estimates - both those for high-school completion and years of schooling - are very small in magnitude and not statistically different from zero regardless of the instruments used, although the first-stage relationship is very strong. We conclude that formal schooling may reduce the probability of job loss for the sample as a whole--the estimated average treatment effect (ATE) is negative and statistically significant (though potentially biased). However, for the subset of individuals whose educational attainment was altered by compulsory schooling laws, there is no evidence of a negative relationship between schooling and the likelihood of job loss - the local average treatment effect (LATE) is not significantly different from zero. Although not shown, we find similar results when

\footnotetext{
${ }^{13}$ The estimated effects of education on the probability of being unemployed in other months conditional on being employed in the first month are similar to those reported here, and are available by request.
} 
we analyze transitions into unemployment from non-participation - less-educated workers are not more likely to become unemployed.

These results suggest that additional formal education at the secondary school level does not influence the incidence of unemployment. Thus there is no evidence of selection into unemployment on the basis of educational attainment, at least for the individuals in our sample whose schooling was affected by compulsory schooling laws.

In summary, our IV estimates indicate that additional schooling at the secondary school level does exert a causal influence on the re-employment outcomes of the unemployed. The magnitudes of the estimated impacts are large. Based on the sample excluding job leavers, high-school completion raises the probability of re-employment within the next 5 months by about 15 percentage points and each year of additional schooling increases the probability of re-employment by 1.5 percentage points.

\section{Results from the Canadian Census}

We also analyse re-employment using Census data, specifically the 1981, 1986, 1991, 1996 and 2001 Public Use Microdata Files. Compared with the LFS, the advantages of census data are its larger sample size, more accurate measures of educational attainment and age, and information on place of birth. Although there are also disadvantages, analysis based on census data can serve as a robustness check.

The Census provides information about each respondent's current labour market status as of the reference week, as well as information about labour market activities in the previous year. Because it provides both retrospective (previous year) and contemporaneous (survey week) information for the same individual, the census has a longitudinal dimension that we exploit in this paper. We define an individual as having 
experienced unemployment in the previous year if she did not work for the full previous calendar year but has recent work experience, as indicated by having worked during the previous calendar year. ${ }^{14}$ Having recent labour market attachment is a strong indication that those who did not work during part of the previous year were searching for jobs. Based on the census data, we measure adaptability to employment shocks by the probability of being re-employed at the time of the survey conditional on being unemployed in the previous year. ${ }^{15}$ This conditional probability is the dependent variable in our empirical analyses.

Following Ferrer and Riddell (2002), we measure years of completed education based on three factors: (i) the highest grade of elementary or secondary school ever attended (a maximum of 13); (ii) years of education completed at a university; and (iii) years of schooling ever completed at an institution other than a university, high school, or elementary school. ${ }^{16}$ The total number of years of schooling is the sum of these three components. ${ }^{17}$

We restrict the sample to those aged 20-64. Individuals not born in Canada are excluded in order to focus on those whose educational attainment was potentially

\footnotetext{
14 There is strong evidence that--contrary to survey instructions--a considerable number of full-year workers excluded their paid vacation or sick leave when reporting their weeks worked in the previous year. Therefore, we follow the advice of Statistics Canada and classify an individual as a full-year worker if the number of reported weeks worked was 49 or more.

${ }^{15}$ Starting from the 1991 Census, one cannot distinguish between paid and unpaid workers based on the class of worker variable. Therefore, re-employed individuals refer to all re-employed workers in our analyses.

${ }^{16}$ Years of education completed at a university is capped at six or more in the public use file, while years of schooling ever completed at an institution other than a university, high school, or elementary school is capped at four or more. Thus the maximum number of years of completed schooling is 23, and for those who did not attend a non-university post-secondary institution, the maximum number of years of education is 19 .

${ }^{17}$ The census public use file reports the highest grade of elementary or secondary school ever attended in two categories for those with less than nine years of schooling: (i) less than five years and (ii) five to eight years. For each category, we take the mid-point (2.5 and 6.5 years respectively) in our analyses. For individuals who reported less than one year of university or non-university post-secondary education, we assigned 0.5 year of schooling.
} 
influenced by Canadian compulsory schooling laws. Because our empirical analyses focus on transitions from unemployment to re-employment, we further restrict the sample to those who were unemployed in the previous year. The resulting sample size is 458,641. As shown by the sample descriptive statistics in Table $7,75 \%$ of those unemployed in the previous year became re-employed as of the census reference week. The average number of years of schooling completed by respondents in our sample is 12.8 and $70 \%$ of our sample had graduated from high school.

\section{OLS Estimates}

OLS results based on census data are similar to those obtained earlier with LFS data. As with the LFS data, we use eight years of schooling or less as the base category and regress the probability of re-employment on the complete set of years of schooling dummies. ${ }^{18}$ The regression also controls for survey year, province/territory, census metropolitan area (CMA), age, gender, marital status, census family size, and language. Based on the coefficient estimates, Figure 3 shows a steady increase in the probability of re-employment as schooling increases. There is a particularly large jump in the reemployment rate between 11 and 12 years of schooling, consistent with high-school completion having an additional effect on the probability of re-employment. The partial relationship is otherwise approximately linear up to 19 years of schooling.

Columns (1) and (4) of Table 8 reveal that graduating from high school is associated with a 7.6-percentage-point increase in the probability of re-employment conditional on being unemployed in the previous year and that an additional year of

\footnotetext{
${ }^{18}$ To create dummy variables for each level of schooling, a half year of schooling was counted as one year. Because the percentage of the population reporting more than 18 years of schooling was only $3.7 \%$, we used the dummy variable for 19 years of schooling to cover all of those having more than 18 years of schooling.
} 
schooling is associated with a 1.3-percentage-point increase in that probability. Estimation results not reported in the table further indicate that males, married people, people aged 35 to 49, CMA residents, and people with a smaller family size are more likely to locate a new job after unemployment than are others. ${ }^{19}$

\section{Estimates}

The IV analyses based on census data use the same instrumental variables for schooling as with the LFS data. Because the information on birthplace is available in census data, we link the census data and data on compulsory schooling laws based on the birthplace of each individual. ${ }^{20}$ The first-stage results shown in the upper panel of Table 8 indicate that our instruments are reasonably strong. IV estimates reported in the bottom panel of Table 8 suggest that graduating from high school increases the probability of re-employment conditional on being unemployed in the previous year by 20 to 27 percentage points, and that an additional year of schooling increases this probability by 1 to 2 percentage points. Irrespective of the instruments used, the IV estimates are all significant at the .01 level. The IV estimates for high-school completion are larger in size than their OLS counterparts, but less precisely estimated and not significantly different from the OLS estimates. The OLS and IV estimates for years of schooling are very similar in size.

To check for the robustness of the findings, we conduct the same analyses with a more restrictive measure of unemployment based on the receipt of Employment Insurance (EI) (known as Unemployment Insurance until 1996) benefits. We define an

\footnotetext{
${ }^{19}$ The effects of education on re-employment are consistent across different census years. For censuses taken in 1986 and later, we further control for minority status and aboriginal status, variables that are not available in the 1981 Census, and there is little change in the results.

${ }^{20}$ Individuals having moved across provinces before age 6 were mismatched for both the school leaving age and school entry age while individuals having moved across provinces between age 6 and age 14 were mismatched for the school leaving age. Because changes in compulsory schooling laws were unlikely to cause people to move across provinces, this should not cause significant bias in our estimates.
} 
individual as having experienced unemployment in the previous year if the individual did not work for the full year and received EI benefits in the previous year. Compared with the measure of unemployment based on work activity in the previous year, the measure of unemployment based on EI benefits receipt is arguably narrower as not all unemployed workers receive EI benefits. Moreover, EI benefits receipt tends to be underreported in survey data. The results based on this more restrictive measure of unemployment are very similar to those based on the measure of unemployment described earlier. ${ }^{21}$

\section{$4 \quad$ Heterogeneity in Educational Impacts}

The empirical results on the effects of education on re-employment success based on both the LFS and census data yield IV estimates that are generally larger than the corresponding OLS estimates (especially estimates of the impact of high-school graduation), although the differences between the two types of estimates are generally not statistically significant. Many recent studies of the causal impacts of education on earnings have obtained similar results (e.g., Card, 2001). One potential explanation for this finding is the existence of measurement error in educational attainment, which results in a downward bias in the OLS estimates (Griliches, 1977; Card, 2001). An alternative explanation is that, in the presence of heterogeneity across individuals in the impacts of additional education, the OLS and IV estimates measure different treatment effects. OLS applied to a sample representative of the population estimates the ATE, which corresponds to the expected impact of additional education for an individual chosen at

\footnotetext{
${ }^{21}$ Due to space limitation, results based on this more restrictive measure of unemployment are not shown here, but are available upon request.
} 
random from the population. In contrast, IV generally estimates a LATE, which corresponds to the expected impact of additional education for the subset of the population whose behaviour was altered by the instrument (Imbens and Angrist, 1994). In the case of instruments based on compulsory schooling laws, IV estimates the impact of additional education among those who obtained more schooling than they otherwise would have chosen to obtain as a consequence of changes in the laws.

One potential source of heterogeneity is the presence of non-linearities in the impacts of schooling. The non-parametric OLS estimates shown in Figure 3 - which allow the relationship between re-employment rates and years of schooling to take any shape - suggest that the relationship is concave, so that the impact of an additional year of school is larger at low levels than at high levels of educational attainment. Under such circumstances, a linear specification of the relationship - as is assumed in our estimates based on years of schooling - will understate the ATE at low levels of schooling and overstate the ATE at high levels. To test this explanation, we re-estimated the OLS estimate reported in Table 8 using different sub-samples defined based on years of schooling. The OLS estimates based on these restricted sub-samples are larger than those based on the full sample, consistent with the presence of diminishing returns to additional years of schooling contributing to the discrepancy between the OLS and the IV estimates. $^{22}$ Oreopoulos (2006b) and Riddell and Song (2011) also find that the gap between OLS and IV estimates of the impact of schooling can be partly attributed to nonlinearities in the impacts of education.

\footnotetext{
${ }^{22}$ For example, restricting the sample to those with years of schooling less than 16 results in an OLS estimate of 0.015 , identical to the IV estimate in column 6 of Table 8 .
} 


\section{$5 \quad$ Conclusions}

In a labour market characterized by constant structural changes, adaptability to employment shocks is important for both individuals' labour market success and the efficiency of the overall market. Studies on whether and how education enhances adaptability to employment shocks have become especially relevant and timely. Our study empirically assesses the causal effects of education on individuals' adaptability to employment shocks in two dimensions: job search intensity; and re-employment success after being unemployed.

Based on data from the LFS and the Canadian Census, we find that bettereducated individuals tend to adopt more active job search strategies than those with less education, and that education significantly increases re-employment success for unemployed workers. Our IV estimates provide clear evidence that the positive association between educational attainment and individuals' adaptability to employment shocks cannot be easily explained away by unobserved factors that are correlated with both variables. Our IV estimates of the impact of education on re-employment are similar in magnitude to those we found with U.S. data, suggesting that this may be a phenomenon that holds in many labour markets (Riddell and Song, 2011).

Several recent studies (e.g., Lochner and Moretti (2004); Milligan, Moretti, and Oreopoulos (2004); and Oreopoulos (2006a)) find that the increased educational attainment brought about by past changes to compulsory schooling laws had large beneficial effects on the lives of those who would otherwise have dropped out of secondary school at an earlier age. Our results provide further evidence for such benefits from additional high-school education. Our findings of positive causal effects of 
education on job search intensity and re-employment success also lend support to the case for education as a "preventative" type of adjustment assistance policy, in contrast to traditional adjustment assistance programs that deal with problems ex post.

The strong positive effects of education on both job search intensity and reemployment success found in our study are consistent with findings from prior research that suggest that job search behaviour plays an important role in re-employment success (Claussen, 1994; Eden and Aviram, 1993; Schaufeli and Van Yperen, 1993). Based on OLS regression results not reported here, we find that job search intensity in a month tends to exert significant and positive impacts on the re-employment success in subsequent months. It would be informative to investigate in future research the extent to which education's effect on re-employment success is mediated through job search intensity. 


\section{References}

Acemoglu, Daron, Joshua Angrist. 2000. "How Large Are Human Capital Externalities? Evidence from Compulsory Schooling Laws.” NBER Macroeconomics Annual 2000: 9-59.

Barron, John M., and Wesley Mellow. 1979. "Search Effort in the Labour Market.” Journal of Human Resources 14: 389-404.

Card, David. 2001. "Estimating the Return to Schooling: Progress on Some Persistent Econometric Problems.” Econometrica 69: 1127-1160.

Claussen, B. 1994. "Psychologically and biochemically assessed stress in a follow-up study of long-term unemployed.” Work and Stress 8: 4-18.

Eden, D., and A. Aviram. 1993. "Self-efficacy Training to Speed Reemployment: Helping People to Help Themselves.” Journal of Applied Psychology 78: 352-360.

Farber, Henry S. 2005. "What Do We Know About Job Loss in the United States? Evidence from the Displaced Workers Survey, 1984-2004.” Economic Perspectives 29(2): 12-18.

Ferrer, Ana M., and W. Craig Riddell. 2002. "The Role of Credentials in the Canadian Labour Market.” Canadian Journal of Economics 35: 879-905.

Fullan, Michael, and Jan J. Loubser. 1972. "Education and Adaptive Capacity." Sociology of Education 45: 271-287.

Goldin, Claudia, and Lawrence F. Katz. 2011. "Mass Secondary Schooling and the State: The Role of State Compulsion in the High School Movement.” Pp. 275-310 in Understanding Long-Run Economic Growth: Geography, Institutions, and the Knowledge Economy, edited by Dora L. Costa and Naomi R. Lamoreaux. University of Chicago Press.

Griliches, Zvi. 1977. "Estimating the Returns to Schooling: Some Econometric Problems.” Econometrica 45: 1-22.

Holzer, Harry J. 1988. "Search Method Used by Unemployed Youth.” Journal of Labor Economics 6: 1-20.

Human Resources Development Canada. 2002. Knowledge Matters: Skills and Learning for Canadians. Ottawa: Human Resources Development Canada.

Imbens, Guido, and Joshua Angrist. 1994. "Identification and Estimation of Local Average Treatment Effects.” Econometrica 62: 467-75.

Jones, Stephen R.G. and W. Craig Riddell. 1999. "The Measurement of Unemployment: An Empirical Approach" Econometrica 67 (January) 147-161.

Jones, Stephen R.G. and W. Craig Riddell . 2006. "Unemployment and Non-Employment: Heterogeneities in Labour Market States" Review of Economics and Statistics 88 (August) 314-323.

Lancaster, Tony, and Stephen Nickell. 1980. "The Analysis of Re-Employment Probabilities for the Unemployed." Journal of the Royal Statistical Society, Series A (General) 143: 141-165.

Lleras-Muney, Adrianna. 2002. "Are Compulsory Attendance and Child Labor Laws Effective? An Analysis from 1915 to 1939.” Journal of Law and Economics 45: 401435.

Lochner, Lance, Enrico Moretti. 2004. "The Effect of Education on Crime: Evidence from Prison Inmates, Arrests and Self-Reports.” American Economic Review 94: 155189. 
Milligan, Kevin, Enrico Moretti and Philip Oreopoulos. 2004. "Does education improve citizenship: Evidence from the U.S. and U.K." Journal of Public Economics 88 (August): 1667-1695.

Mincer, Jacob. 1991. "Education and Unemployment.” NBER Working Paper No. 3838.

Nickell, Stephen. 1979. "Estimating the Probability of Leaving Unemployment." Econometrica 47: 1249-1266.

Oreopoulos, Philip. 2006a. "The compelling effects of compulsory schooling: Evidence from Canada” Canadian Journal of Economics 39 (February) 22-52.

Oreopoulos, Philip. 2006b. "Average Treatment Effects of Education when Compulsory School Laws Really Matter.” American Economic Review 96 (1): 152-175.

Riddell, W. Craig. 2005. "Why is Canada's Unemployment Rate Persistently Higher than in the United States?” Canadian Public Policy 31 (March) 93-100.

Riddell, W. Craig and Xueda Song. 2011. "The Impact of Education on Unemployment Incidence and Re-employment Success: Evidence from the U.S. Labor Market.” Labour Economics, Volume 18, Issue 4, pp.453-463.

Schaufeli, W. B., and N. W. Van Yperen. 1993. "Success and Failure in the Labour Market.” Journal of Organizational Behaviour 14: 559-572.

Schmidt, Stefanie. 1996. "School Quality, Compulsory Education Laws, and the Growth of American High School Attendance, 1915-1935.” Ph.D. dissertation, MIT.

Stock, James H., Jonathan H. Wright and Motohiro Yogo. 2002. "A Survey of Weak Instruments and Weak Identification in Generalized Method of Moments" Journal of Business and Economic Statistics 20 (4): 518-529.

Wadsworth, Jonathan. 1991. "Unemployment Benefits and Search Effort in the U.K. Labour Market” Economica 58 (February) 17-34.

Yoon, Bong Joon. 1981. "A Model of Unemployment Duration with Variable Search Intensity.” The Review of Economics and Statistics 63: 599-609. 
Table 1

Descriptive Statistics for Labour Force Survey (1976-1996) in the Analyses of Job Search Intensity

Number of observations: 451,120

\begin{tabular}{lcc}
\hline \multicolumn{1}{c}{ Variable } & Mean & Std. dev. \\
\hline Job search intensity & 1.645 & 0.825 \\
0 to 8 years & 0.119 & 0.324 \\
Some secondary or high-school graduate & 0.505 & 0.500 \\
Some post-secondary & 0.112 & 0.316 \\
Post-secondary certificate or diploma & 0.178 & 0.383 \\
University degree & 0.086 & 0.281 \\
Years of schooling & 11.378 & 3.297 \\
High-school graduation & 0.680 & 0.467 \\
Unmarried & 0.447 & 0.497 \\
Female & 0.447 & 0.497 \\
Age & 32.853 & 10.368 \\
School leaving age $=12$ & 0.002 & 0.046 \\
School leaving age $=13$ & 0.000 & 0.011 \\
School leaving age $=14$ & 0.090 & 0.286 \\
School leaving age $=15$ & 0.423 & 0.494 \\
School leaving age $=16$ & 0.484 & 0.500 \\
School entry age $=6$ & 0.605 & 0.489 \\
School entry age $=7$ & 0.320 & 0.467 \\
School entry age $=8$ & 0.074 & 0.262 \\
\hline
\end{tabular}

Note: Sampling weights are used in all statistics. 
Table 2

Estimates of the Effects of High-school Graduation and Years of Schooling on Job Search Intensity

Data source: Labour Force Survey (1976-1996)

Number of observations: 451,120

\begin{tabular}{|c|c|c|c|c|c|c|}
\hline & \multicolumn{3}{|c|}{$\begin{array}{l}\text { Endogenous variable is high-school } \\
\text { graduation }\end{array}$} & \multicolumn{3}{|c|}{$\begin{array}{c}\text { Endogenous variable is years } \\
\text { of schooling }\end{array}$} \\
\hline & \multirow{2}{*}{$\begin{array}{c}\text { OLS } \\
(1)\end{array}$} & \multicolumn{2}{|c|}{ IV } & \multirow{2}{*}{$\begin{array}{c}\text { OLS } \\
(4)\end{array}$} & \multicolumn{2}{|c|}{ IV } \\
\hline & & (2) & (3) & & (5) & (6) \\
\hline \multicolumn{7}{|l|}{ First stage } \\
\hline School leaving age $=14$ & & $\begin{array}{c}0.072 * * * \\
(0.013)\end{array}$ & $\begin{array}{c}0.064 * * * \\
(0.014)\end{array}$ & & $\begin{array}{c}0.634 * * * \\
(0.125)\end{array}$ & $\begin{array}{c}0.560 * * * \\
(0.128)\end{array}$ \\
\hline School leaving age $=15$ & & $\begin{array}{c}0.174 * * * \\
(0.015)\end{array}$ & $\begin{array}{c}0.168 * * * \\
(0.014)\end{array}$ & & $\begin{array}{c}1.751 * * * \\
(0.132)\end{array}$ & $\begin{array}{c}1.692 * * * \\
(0.126)\end{array}$ \\
\hline School leaving age $=16$ & & $\begin{array}{c}0.151^{* * *} \\
(0.013)\end{array}$ & $\begin{array}{c}0.148 * * * \\
(0.013)\end{array}$ & & $\begin{array}{l}1.497 * * * \\
(0.119)\end{array}$ & $\begin{array}{c}1.466^{* * *} \\
(0.118)\end{array}$ \\
\hline School entry age $=6$ & & & $\begin{array}{l}-0.014 \\
(0.010)\end{array}$ & & & $\begin{array}{l}-0.138 \\
(0.087)\end{array}$ \\
\hline School entry age=7 & & & $\begin{array}{l}-0.002 \\
(0.016)\end{array}$ & & & $\begin{array}{l}-0.040 \\
(0.124)\end{array}$ \\
\hline $\begin{array}{l}\text { F-statistic for exclusion } \\
\text { of instruments }\end{array}$ & & 55.84 & 35.10 & & 79.24 & 50.46 \\
\hline$p$-value & & 0.000 & 0.000 & & 0.000 & 0.000 \\
\hline \multicolumn{7}{|c|}{$\begin{array}{l}\text { Second stage: Dependent variable is number of active job search methods used in a month } \\
\text { conditional on being unemployed in that month. }\end{array}$} \\
\hline High-school graduation & $\begin{array}{c}0.122^{* * *} \\
(0.004)\end{array}$ & $\begin{array}{l}0.170^{*} \\
(0.087)\end{array}$ & $\begin{array}{l}0.147^{*} \\
(0.086)\end{array}$ & & & \\
\hline Years of schooling & & & & $\begin{array}{c}0.020^{* * *} \\
(0.001)\end{array}$ & $\begin{array}{r}0.016^{* *} \\
(0.008)\end{array}$ & $\begin{array}{l}0.014^{*} \\
(0.008) \\
\end{array}$ \\
\hline
\end{tabular}

Note: All regressions control for survey year, survey month, province of residence, nine age groups (age 20-24, 25-29, and so on), gender, and marital status. The robust standard errors corrected for province of residence and year of birth clustering are in parentheses. All regressions are weighted by the final individual or family weights.

* Significant at the $10 \%$ level.

$* *$ Significant at the $5 \%$ level.

$* * *$ Significant at the $1 \%$ level. 
Table 3

Descriptive Statistics for Labour Force Survey (1976-1996) in the Analyses of Reemployment

\begin{tabular}{|c|c|c|c|c|}
\hline \multirow[b]{2}{*}{ Variable } & \multicolumn{2}{|c|}{$\begin{array}{l}\text { All unemployed } \\
(\mathrm{N}=249,330)\end{array}$} & \multicolumn{2}{|c|}{$\begin{array}{c}\text { Unemployed excluding } \\
\text { job leavers } \\
(\mathrm{N}=212,218) \\
\end{array}$} \\
\hline & Mean & Std. Dev. & Mean & Std. Dev. \\
\hline Re-employ in second month & 0.157 & 0.364 & 0.153 & 0.360 \\
\hline Re-employ in third month & 0.212 & 0.409 & 0.210 & 0.407 \\
\hline Re-employ in forth month & 0.235 & 0.424 & 0.235 & 0.424 \\
\hline Re-employ in fifth month & 0.241 & 0.428 & 0.243 & 0.429 \\
\hline Re-employ in sixth month & 0.235 & 0.424 & 0.238 & 0.426 \\
\hline Re-employ any time while in survey & 0.402 & 0.490 & 0.401 & 0.490 \\
\hline 0 to 8 years & 0.115 & 0.319 & 0.120 & 0.325 \\
\hline Some secondary or high-school graduate & 0.519 & 0.500 & 0.517 & 0.500 \\
\hline Some post-secondary & 0.102 & 0.303 & 0.100 & 0.300 \\
\hline Post-secondary certificate or diploma & 0.177 & 0.382 & 0.178 & 0.382 \\
\hline University degree & 0.087 & 0.282 & 0.085 & 0.279 \\
\hline Years of schooling & 11.380 & 3.268 & 11.318 & 3.308 \\
\hline High-school graduation & 0.675 & 0.468 & 0.666 & 0.472 \\
\hline Duration of unemployment & 21.934 & 25.247 & 23.427 & 26.652 \\
\hline Economic family size & 2.909 & 1.355 & 2.932 & 1.357 \\
\hline Unmarried & 0.465 & 0.499 & 0.468 & 0.499 \\
\hline Female & 0.434 & 0.496 & 0.423 & 0.494 \\
\hline Age & 32.934 & 10.344 & 33.095 & 10.350 \\
\hline School leaving age $=12$ & 0.002 & 0.042 & 0.002 & 0.043 \\
\hline School leaving age $=13$ & 0.000 & 0.010 & 0.000 & 0.010 \\
\hline School leaving age $=14$ & 0.099 & 0.299 & 0.101 & 0.302 \\
\hline School leaving age $=15$ & 0.441 & 0.497 & 0.448 & 0.497 \\
\hline School leaving age $=16$ & 0.458 & 0.498 & 0.448 & 0.497 \\
\hline School entry age $=6$ & 0.580 & 0.494 & 0.587 & 0.492 \\
\hline School entry age $=7$ & 0.336 & 0.472 & 0.329 & 0.470 \\
\hline School entry age $=8$ & 0.084 & 0.278 & 0.083 & 0.276 \\
\hline
\end{tabular}

Note: Duration of unemployment is measured in weeks. Sampling weights are used in all statistics. 
Table 4

Estimates of the Effect of High-school Graduation on Probability of Re-employment

Data source: Labour Force Survey (1976-1996)

\begin{tabular}{|c|c|c|c|c|c|c|}
\hline & \multicolumn{3}{|c|}{$\begin{array}{l}\text { All unemployed } \\
(\mathrm{N}=249,330)\end{array}$} & \multicolumn{3}{|c|}{$\begin{array}{l}\text { Unemployed excluding job leavers } \\
\qquad(\mathrm{N}=212,218)\end{array}$} \\
\hline & \multirow{2}{*}{$\begin{array}{l}\text { OLS } \\
(1)\end{array}$} & \multicolumn{2}{|c|}{ IV } & \multirow{2}{*}{$\begin{array}{c}\text { OLS } \\
(4)\end{array}$} & \multicolumn{2}{|c|}{ IV } \\
\hline & & $(2)$ & $(3)$ & & $(5)$ & (6) \\
\hline \multicolumn{7}{|c|}{ First stage: Dependent variable is high-school graduation. } \\
\hline School leaving age $=14$ & & $\begin{array}{c}0.083 * * * \\
(0.016)\end{array}$ & $\begin{array}{l}0.086 * * * \\
(0.017)\end{array}$ & & $\begin{array}{c}0.083 * * * \\
(0.017)\end{array}$ & $\begin{array}{c}0.087 * * * \\
(0.018)\end{array}$ \\
\hline School leaving age $=15$ & & $\begin{array}{c}0.199 * * * \\
(0.017)\end{array}$ & $\begin{array}{c}0.197 * * * \\
(0.018)\end{array}$ & & $\begin{array}{c}0.201^{* * *} \\
(0.018)\end{array}$ & $\begin{array}{c}0.201^{* * *} \\
(0.019)\end{array}$ \\
\hline School leaving age $=16$ & & $\begin{array}{c}0.153 * * * \\
(0.016)\end{array}$ & $\begin{array}{c}0.153 * * * \\
(0.016)\end{array}$ & & $\begin{array}{c}0.151^{* * *} \\
(0.017)\end{array}$ & $\begin{array}{c}0.152^{* * *} \\
(0.017)\end{array}$ \\
\hline School entry age $=6$ & & & $\begin{array}{c}0.006 \\
(0.011)\end{array}$ & & & $\begin{array}{c}0.007 \\
(0.011)\end{array}$ \\
\hline School entry age=7 & & & $\begin{array}{l}0.041^{* *} \\
(0.018)\end{array}$ & & & $\begin{array}{l}0.036^{*} \\
(0.020)\end{array}$ \\
\hline $\begin{array}{l}\text { F-statistic for exclusion } \\
\text { of instruments }\end{array}$ & & 54.67 & 36.41 & & 53.27 & 34.07 \\
\hline$p$-value & & 0.000 & 0.000 & & 0.000 & 0.000 \\
\hline \multicolumn{7}{|c|}{$\begin{array}{l}\text { Second stage: Dependent variable is an indicator variable for being re-employed in the sixth } \\
\text { month of rotation conditional on being unemployed in the first month of rotation. }\end{array}$} \\
\hline High-school graduation & $\begin{array}{c}0.047^{* * *} \\
(0.003)\end{array}$ & $\begin{array}{c}0.158 * * * \\
(0.049)\end{array}$ & $\begin{array}{c}0.156 * * * \\
(0.046)\end{array}$ & $\begin{array}{c}0.049 * * * \\
(0.004)\end{array}$ & $\begin{array}{c}0.128 * * * \\
(0.049)\end{array}$ & $\begin{array}{c}0.132 * * * \\
(0.047)\end{array}$ \\
\hline \multicolumn{7}{|c|}{$\begin{array}{l}\text { Second stage: Dependent variable is an indicator variable for being re-employed any time between the } \\
\text { second and sixth month of rotation conditional on being unemployed in the first month of rotation. }\end{array}$} \\
\hline High-school graduation & $\begin{array}{c}0.060^{* * *} \\
(0.004)\end{array}$ & $\begin{array}{c}0.163^{* *} \\
(0.068)\end{array}$ & $\begin{array}{c}0.154^{* *} \\
(0.064)\end{array}$ & $\begin{array}{c}0.061^{* * *} \\
(0.004)\end{array}$ & $\begin{array}{r}0.153 * * \\
(0.068)\end{array}$ & $\begin{array}{r}0.148 * * \\
(0.066)\end{array}$ \\
\hline
\end{tabular}

Note: All regressions control for survey year, survey month, province of residence, nine age groups (age 20-24, 25-29, and so on), gender, marital status, economic family size, and duration of unemployment. The robust standard errors corrected for province of residence and year of birth clustering are in parentheses. All regressions are weighted by the final individual or family weights.

*Significant at the $10 \%$ level.

$* *$ Significant at the $5 \%$ level.

$* * *$ Significant at the $1 \%$ level. 
Table 5

Estimates of the Effect of Years of Schooling on Probability of Re-employment

Data source: Labour Force Survey (1976-1996)

\begin{tabular}{|c|c|c|c|c|c|c|}
\hline & \multicolumn{3}{|c|}{$\begin{array}{l}\text { All unemployed } \\
(\mathrm{N}=249,330)\end{array}$} & \multicolumn{3}{|c|}{$\begin{array}{l}\text { Unemployed excluding job leavers } \\
\qquad(\mathrm{N}=212,218)\end{array}$} \\
\hline & \multirow{2}{*}{$\begin{array}{l}\text { OLS } \\
(1)\end{array}$} & \multicolumn{2}{|c|}{ IV } & \multirow{2}{*}{$\begin{array}{l}\text { OLS } \\
(4)\end{array}$} & \multicolumn{2}{|c|}{ IV } \\
\hline & & (2) & (3) & & (5) & (6) \\
\hline \multicolumn{7}{|c|}{ First stage: Dependent variable is years of schooling. } \\
\hline School leaving age $=14$ & & $\begin{array}{c}0.726 * * * \\
(0.142)\end{array}$ & $\begin{array}{c}0.744^{* * *} \\
(0.146)\end{array}$ & & $\begin{array}{c}0.755^{* * *} \\
(0.145)\end{array}$ & $\begin{array}{c}0.780 * * * \\
(0.150)\end{array}$ \\
\hline School leaving age $=15$ & & $\begin{array}{c}1.886 * * * \\
(0.146)\end{array}$ & $\begin{array}{l}1.875 * * * \\
(0.147)\end{array}$ & & $\begin{array}{l}1.926 * * * \\
(0.149)\end{array}$ & $\begin{array}{l}1.926 * * * \\
(0.151)\end{array}$ \\
\hline School leaving age $=16$ & & $\begin{array}{c}1.479 * * * \\
(0.137)\end{array}$ & $\begin{array}{c}1.483 * * * \\
(0.139)\end{array}$ & & $\begin{array}{c}1.490 * * * \\
(0.140)\end{array}$ & $\begin{array}{c}1.498 * * * \\
(0.141)\end{array}$ \\
\hline School entry age=6 & & & $\begin{array}{c}0.039 \\
(0.085)\end{array}$ & & & $\begin{array}{c}0.053 \\
(0.091)\end{array}$ \\
\hline School entry age=7 & & & $\begin{array}{c}0.265^{* *} \\
(0.124)\end{array}$ & & & $\begin{array}{l}0.240^{*} \\
(0.134)\end{array}$ \\
\hline $\begin{array}{l}\text { F-statistic for exclusion } \\
\text { of instruments }\end{array}$ & & 78.72 & 53.21 & & 80.65 & 52.92 \\
\hline$p$-value & & 0.000 & 0.000 & & 0.000 & 0.000 \\
\hline \multicolumn{7}{|c|}{$\begin{array}{l}\text { Second stage: Dependent variable is an indicator variable for being re-employed in the sixth } \\
\text { month of rotation conditional on being unemployed in the first month of rotation. }\end{array}$} \\
\hline Years of schooling & $\begin{array}{c}0.007 * * * \\
(0.001)\end{array}$ & $\begin{array}{c}0.016 * * * \\
(0.005)\end{array}$ & $\begin{array}{c}0.016 * * * \\
(0.005)\end{array}$ & $\begin{array}{c}0.007^{* * *} \\
(0.001)\end{array}$ & $\begin{array}{c}0.013^{* * *} \\
(0.005)\end{array}$ & $\begin{array}{c}0.013^{* * *} \\
(0.005)\end{array}$ \\
\hline \multicolumn{7}{|c|}{$\begin{array}{l}\text { Second stage: Dependent variable is an indicator variable for being re-employed any time between the } \\
\text { second and sixth month of rotation conditional on being unemployed in the first month of rotation. }\end{array}$} \\
\hline Years of schooling & $\begin{array}{c}0.009 * * * \\
(0.001)\end{array}$ & $\begin{array}{c}0.016^{* *} \\
(0.007) \\
\end{array}$ & $\begin{array}{c}0.016^{* *} \\
(0.006)\end{array}$ & $\begin{array}{c}0.009 * * * \\
(0.001)\end{array}$ & $\begin{array}{l}0.015^{* *} \\
(0.007)\end{array}$ & $\begin{array}{c}0.015^{* *} \\
(0.007)\end{array}$ \\
\hline
\end{tabular}

Note: All regressions control for survey year, survey month, province of residence, nine age groups (age 20-24, 25-29, and so on), gender, marital status, economic family size, and duration of unemployment. The robust standard errors corrected for province of residence and year of birth clustering are in parentheses. All regressions are weighted by the final individual or family weights.

$*$ Significant at the $10 \%$ level.

$* *$ Significant at the $5 \%$ level.

$* * *$ Significant at the $1 \%$ level. 


\section{Table 6}

\section{Estimates of the Effects of High-school Graduation and Years of Schooling on Probability of Job Loss}

Data source: Labour Force Survey (1976-1996)

Number of observations: 2,359,682

\begin{tabular}{|c|c|c|c|c|c|c|}
\hline & \multicolumn{3}{|c|}{$\begin{array}{l}\text { Endogenous variable is high-school } \\
\text { graduation }\end{array}$} & \multicolumn{3}{|c|}{$\begin{array}{l}\text { Endogenous variable is years of } \\
\text { schooling }\end{array}$} \\
\hline & \multirow{2}{*}{$\begin{array}{c}\text { OLS } \\
(1)\end{array}$} & \multicolumn{2}{|c|}{ IV } & \multirow{2}{*}{$\begin{array}{l}\text { OLS } \\
(4)\end{array}$} & \multicolumn{2}{|c|}{ IV } \\
\hline & & $(2)$ & (3) & & (5) & (6) \\
\hline \multicolumn{7}{|l|}{ First stage } \\
\hline School leaving age $=14$ & & $\begin{array}{c}0.061^{* * *} \\
(0.009)\end{array}$ & $\begin{array}{c}0.061^{* * *} \\
(0.010)\end{array}$ & & $\begin{array}{c}0.534 * * * \\
(0.079)\end{array}$ & $\begin{array}{c}0.573 * * * \\
(0.088)\end{array}$ \\
\hline School leaving age $=15$ & & $\begin{array}{c}0.138 * * * \\
(0.011)\end{array}$ & $\begin{array}{c}0.134 * * * \\
(0.011)\end{array}$ & & $\begin{array}{c}1.313^{* * *} \\
(0.089)\end{array}$ & $\begin{array}{c}1.305^{* * *} \\
(0.090)\end{array}$ \\
\hline School leaving age $=16$ & & $\begin{array}{c}0.122^{* * *} \\
(0.009)\end{array}$ & $\begin{array}{c}0.121^{* * *} \\
(0.009)\end{array}$ & & $\begin{array}{c}1.191 * * * \\
(0.081)\end{array}$ & $\begin{array}{c}1.200^{* * *} \\
(0.081)\end{array}$ \\
\hline School entry age $=6$ & & & $\begin{array}{l}-0.002 \\
(0.008)\end{array}$ & & & $\begin{array}{c}0.064 \\
(0.062)\end{array}$ \\
\hline School entry age $=7$ & & & $\begin{array}{c}0.039 \\
(0.010)\end{array}$ & & & $\begin{array}{c}0.436 * * * \\
(0.090)\end{array}$ \\
\hline $\begin{array}{l}\text { F-statistic for exclusion } \\
\text { of instruments }\end{array}$ & & 80.59 & 68.37 & & 107.55 & 89.74 \\
\hline$p$-value & & 0.000 & 0.000 & & 0.000 & 0.000 \\
\hline \multicolumn{7}{|c|}{$\begin{array}{l}\text { Second stage: Dependent variable is an indicator variable for being unemployed in the second month of } \\
\text { rotation conditional on being employed in the first month of rotation. } \\
\text { Mean of dependent variable }=0.017\end{array}$} \\
\hline High-school graduation & $\begin{array}{l}-0.012 * * * \\
(0.000)\end{array}$ & $\begin{array}{l}-0.003 \\
(0.006)\end{array}$ & $\begin{array}{l}-0.006 \\
(0.006)\end{array}$ & & & \\
\hline Years of schooling & & & & $\begin{array}{c}-0.002^{* * *} \\
(0.000)\end{array}$ & $\begin{array}{l}-0.000 \\
(0.001)\end{array}$ & $\begin{array}{c}-0.001 \\
(0.001)\end{array}$ \\
\hline
\end{tabular}

Note: All regressions control for survey year, survey month, province of residence, nine age groups (age 20-24, 25-29, and so on), gender, and marital status. The robust standard errors corrected for province of residence and year of birth clustering are in parentheses. All regressions are weighted by the final individual or family weights.

* Significant at the $10 \%$ level.

** Significant at the $5 \%$ level.

$* * *$ Significant at the $1 \%$ level. 
Table 7

Descriptive Statistics for Canadian Census (1981-2001)

Number of observations: 458,641

\begin{tabular}{lcc}
\hline \multicolumn{1}{c}{ Variable } & Mean & Std. dev. \\
\hline Re-employment & 0.750 & 0.433 \\
Years of schooling & 12.836 & 3.188 \\
High-school graduation & 0.701 & 0.458 \\
1986 census & 0.170 & 0.375 \\
1991 census & 0.237 & 0.425 \\
1996 census & 0.231 & 0.422 \\
2001 census & 0.224 & 0.417 \\
Census family size & 2.916 & 1.403 \\
English only & 0.621 & 0.485 \\
French only & 0.162 & 0.368 \\
English and French & 0.217 & 0.412 \\
Female & 0.511 & 0.500 \\
Unmarried & 0.413 & 0.492 \\
School leaving age $=12$ & 0.002 & 0.045 \\
School leaving age $=13$ & 0.000 & 0.012 \\
School leaving age $=14$ & 0.096 & 0.295 \\
School leaving age $=15$ & 0.386 & 0.487 \\
School leaving age $=16$ & 0.516 & 0.500 \\
School entry age $=6$ & 0.627 & 0.484 \\
School entry age $=7$ & 0.307 & 0.461 \\
School entry age $=8$ & 0.066 & 0.248 \\
\hline
\end{tabular}




\section{Table 8}

\section{Estimates of the Effects of High-school Graduation and Years of Schooling on Probability of Re-employment Conditional on Being Unemployed in the Previous Year}

Data source: Canadian Census (1981-2001)

Number of observations: 458,641

\begin{tabular}{|c|c|c|c|c|c|c|}
\hline & \multicolumn{3}{|c|}{$\begin{array}{l}\text { Endogenous variable is high-school } \\
\text { graduation }\end{array}$} & \multicolumn{3}{|c|}{$\begin{array}{l}\text { Endogenous variable is years of } \\
\text { schooling }\end{array}$} \\
\hline & \multirow{2}{*}{$\begin{array}{l}\text { OLS } \\
(1)\end{array}$} & \multicolumn{2}{|c|}{ IV } & \multirow{2}{*}{$\begin{array}{l}\text { OLS } \\
(4)\end{array}$} & \multicolumn{2}{|c|}{ IV } \\
\hline & & (2) & (3) & & (5) & (6) \\
\hline \multicolumn{7}{|l|}{ First stage } \\
\hline School leaving age $=14$ & & $\begin{array}{c}0.060^{* * *} \\
(0.014)\end{array}$ & $\begin{array}{c}0.063 * * * \\
(0.015)\end{array}$ & & $\begin{array}{c}0.643^{* * *} \\
(0.116)\end{array}$ & $\begin{array}{c}0.551^{* * *} \\
(0.127)\end{array}$ \\
\hline School leaving age $=15$ & & $\begin{array}{c}0.110^{* * *} \\
(0.014)\end{array}$ & $\begin{array}{c}0.114^{* * *} \\
(0.015)\end{array}$ & & $\begin{array}{l}1.484^{* * *} \\
(0.116)\end{array}$ & $\begin{array}{c}1.436^{* * *} \\
(0.118)\end{array}$ \\
\hline School leaving age $=16$ & & $\begin{array}{c}0.108^{* * * *} \\
(0.014)\end{array}$ & $\begin{array}{c}0.108 * * * \\
(0.015)\end{array}$ & & $\begin{array}{c}1.389 * * * \\
(0.120)\end{array}$ & $\begin{array}{c}1.299 * * * \\
(0.124)\end{array}$ \\
\hline School entry age $=6$ & & & $\begin{array}{c}0.033 * * * \\
(0.007)\end{array}$ & & & $\begin{array}{l}-0.028 \\
(0.070)\end{array}$ \\
\hline School entry age $=7$ & & & $\begin{array}{c}0.007 \\
(0.008)\end{array}$ & & & $\begin{array}{c}-0.234^{* * * *} \\
(0.079)\end{array}$ \\
\hline $\begin{array}{l}F \text {-statistic for exclusion } \\
\text { of instruments }\end{array}$ & & 32.00 & 27.22 & & 94.00 & 56.86 \\
\hline$p$-value & & 0.000 & 0.000 & & 0.000 & 0.000 \\
\hline \multicolumn{7}{|c|}{$\begin{array}{l}\text { Second stage: Dependent variable is an indicator variable for being re-employed conditional on being } \\
\text { unemployed in the previous year. }\end{array}$} \\
\hline High-school graduation & $\begin{array}{c}0.076^{* * *} \\
(0.002)\end{array}$ & $\begin{array}{c}0.201 * * * \\
(0.066)\end{array}$ & $\begin{array}{c}0.267 * * * \\
(0.060)\end{array}$ & & & \\
\hline Years of schooling & & & & $\begin{array}{c}0.013 * * * \\
(0.000)\end{array}$ & $\begin{array}{c}0.013 * * * \\
(0.004)\end{array}$ & $\begin{array}{c}0.015^{* * *} \\
(0.004)\end{array}$ \\
\hline
\end{tabular}

Note: All regressions control for survey year, province/territory, CMA (Toronto, Montreal, Vancouver, or other CMA), nine age groups (age 20-24, 25-29, and so on), gender, marital status, census family size, and language. The robust standard errors corrected for province and year of birth clustering are in parentheses.

$*$ Significant at the $10 \%$ level.

$* *$ Significant at the $5 \%$ level.

$* * *$ Significant at the $1 \%$ level. 


\section{Figure 1}

Regression-Adjusted Job Search Intensity by Educational Attainment

Data source: Labour Force Survey (1976-1996)

Number of observations: 451,120

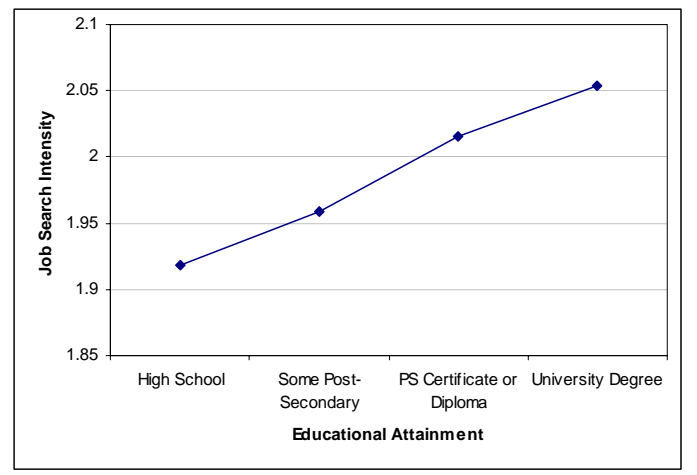

Note: Regression-adjusted job search intensity is obtained by conditioning on survey year, survey month, province of residence, nine age groups (age 20-24, 25-29, and so on), gender, and marital status. This graph displays the coefficient estimates on the complete set of educational attainment dummies. The intercept applies to the base category -males surveyed in January 1976 who were 35 to 39 years of age, had eight years of schooling or less, were married, and lived in Ontario at the time of the survey. All regressions are weighted by the final individual or family weights.

\section{Figure 2}

Regression-Adjusted Probability of Re-employment in the Sixth Month of Rotation Conditional on Being Unemployed in the First Month by Educational Attainment

Data source: Labour Force Survey (1976-1996)

Number of observations: 249,330

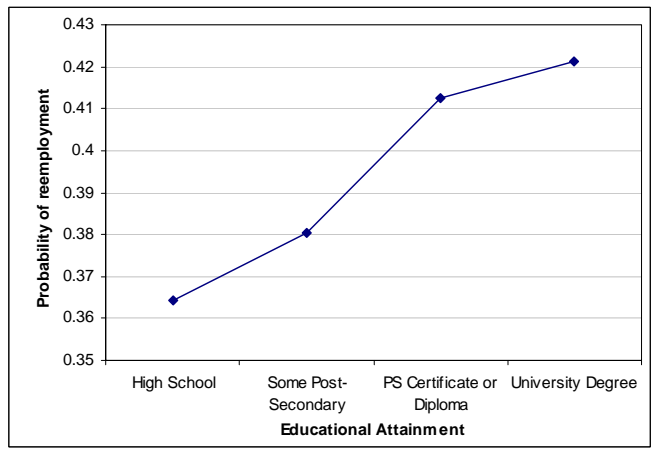

Note: Regression-adjusted probabilities of re-employment are obtained by conditioning on survey year, survey month, province of residence, nine age groups (age 20-24, 25-29, and so on), gender, marital status, economic family size, and duration of unemployment. This graph displays the coefficient estimates on the complete set of educational attainment dummies. The intercept applies to the base category -- married males surveyed in January 1976 who were 35 to 39 years of age, had eight years of schooling or less, lived in Ontario at the time of the survey, had mean economic family size and mean duration of unemployment. All regressions are weighted by the final individual or family weights. 


\section{Figure 3}

\section{Regression-Adjusted Probability of Re-employment Conditional on Being}

Unemployed in the Previous Year by Years of Schooling

Data source: Canadian Census (1981-2001)

Number of observations: 458,641

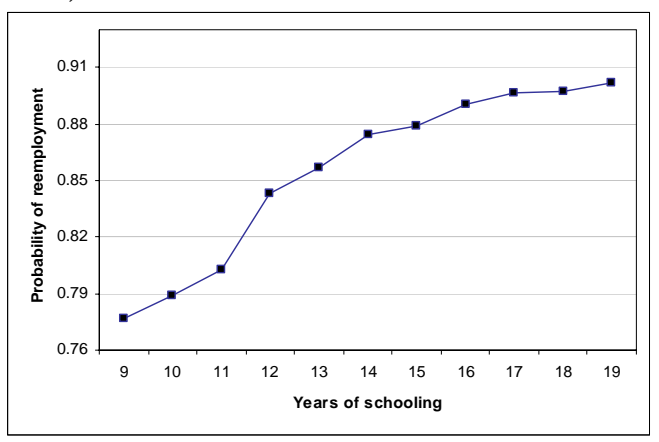

Note: Regression-adjusted probability of re-employment are obtained by conditioning on survey year, province/territory, CMA (Toronto, Montreal, Vancouver, or other CMA), nine age groups (age 20-24, 25-29, and so on), gender, marital status, census family size, and language. This graph displays the coefficient estimates on the complete set of schooling dummies. The intercept applies to the base category -- males surveyed in 1981 who were 35 to 39 years of age, had eight years of schooling or less, were married, lived in a CMA other than Toronto, Montreal, or Vancouver, lived in Ontario, only spoke English at the time of the survey, and had mean census family size. 